\title{
Influence of different species of aphid prey on the immature survival and development of four species of aphidophagous coccinellids (Coleoptera: Coccinellidae)
}

\author{
Dimitrios P. PAPACHRISTOS ${ }^{1}$, IOANNA KATSAROU ${ }^{2}$, ANTONIOS MICHAELAKIS ${ }^{1}$ and Nikos E. PAPANIKOLAOU ${ }^{1}$ \\ ${ }^{1}$ Department of Entomology and Agricultural Zoology, Benaki Phytopathological Institute, 8 St. Delta Str., 14561 Kifissia, Athens, \\ Greece; e-mails: d.papachristos@bpi.gr; a.michaelakis@bpi.gr; nepapanikolaou@yahoo.gr \\ ${ }^{2}$ Department of Plant Production, Technological Educational Institute of Epirus, Kostakioi Artas, 47100 Arta, Greece; \\ e-mail: jdkatsarou@yahoo.gr
}

\begin{abstract}
Key words. Coleoptera, Coccinellidae, Coccinella septempunctata, Ceratomegilla undecimnotata, Propylea quatuordecimpunctata, Oenopia conglobata, Aphididae, Aphis fabae, Macrosiphoniella sanborni, Brevicoryne brassicae, aphid prey, survival, development, aphid host plant
\end{abstract}

\begin{abstract}
This study was on the effect of three species of aphids (Aphis fabae, Macrosiphoniella sanborni, Brevicoryne brassicae) on the survival, growth and development of the immature stages of the aphidophagous coccinellids Coccinella septempunctata, Ceratomegilla undecimnotata, Propylea quatuordecimpunctata and Oenopia conglobata. The percentage survival was lowest, immature development most prolonged and the adults the lightest when these predators were fed on B. brassicae. In addition, C. septempunctata and C. undecimnotata performed better when fed on M. sanborni ( 74.1 and $72.0 \%$ total immature survival, respectively) than $P$. quatuordecimpunctata and O. conglobata ( 25.0 and $13.8 \%$ total immature survival, respectively). In addition, the host plant of $A$. fabae also had a significant effect on the performance of the predators. These coccinellids survived best, had shorter developmental times and were heavier as adults when fed on A. fabae reared on Vicia faba than on Phaseolus vulgaris. These results may be useful for improving the effectiveness of biological control practice and the production of coccinellids in an insectary.
\end{abstract}

\section{INTRODUCTION}

Coccinellids are predators of several pest species, especially aphids, whiteflies, coccids, mealybugs and spider mites, and important components of biological control in many crops (Obrycki \& Kring, 1998; Iperti, 1999). Important factors affecting the performance of insect predators are the nutritional value and availability of prey (Francis et al., 2001a). In particular, the abundance of aphidophagous coccinellids is affected, among other factors, by the quality and quantity of aphid prey, as some aphids and their host plants are toxic for predators (Hodek, 1993; Kamo et al., 2010; Hodek \& Evans, 2012).

The effect of prey on the development and survival of aphidophagous coccinellids is well studied for some common species (e.g. Hauge et al., 1998; Kalushokov \& Hodek, 2004; Omkar \& Pervez, 2005; Pervez \& Omkar, 2006; Hodek \& Michaud, 2008). Aphid prey may adversely affect the survival and development of larvae (Kamo et al., 2010) and their availability during the larval stage may affect adult fitness (Dmitriew \& Rowe, 2011). In addition, plant species can affect parasitoids and predators directly or indirectly through multitrophic interactions (Price et al., 1980). Plant biochemistry may affect the nutritional value of herbivores and in turn affect the various life history parameters of their natural enemies (Giles et al., 2002). Also, plant physical characteristics, like trichomes, and architecture (morphological complexity) may affect predators by impeding their movement and effectiveness, and reducing their survival (Carter et al., 1984; Clark \& Messina, 1998; Legrand \& Barbosa, 2003).

Ceratomegilla undecimnotata (Schneider), Propylea quatuordecimpunctata (L.), Oenopia conglobata (L.) and Coccinella septempunctata L. (Coleoptera: Coccinellidae) are widespread species of coccinellid, which are considered to be important biological control agents (Hodek \& Honěk, 1996). In particular, C. undecimnotata is a common European species that feeds on a great number of species of aphids that infest cultivated and non-cultivated plants (Iperti, 1999; Kavallieratos et al., 2004; Katsoyannos et al., 2005). P. quatuordecimpunctata is a widely distributed Palearctic aphidophagous species that is well established in Canada and has spread into the United States; it feeds on many economically important aphids on a wide range of crops (Honěk, 1985; Wheeler, 1990; Obrycki et al., 1993; Freier et al., 2007; Pervez \& Omkar, 2011). O. conglobata is also a widespread coccinellid predator in Europe and Asia, and also feeds on many species of aphid (Aslan \& Uygun, 2005; Yaşar \& Özger, 2005; Khan et al., 2007). C. septempunctata L. is the most common Palearctic aphidophagous coccinellid predominant in various coccinellid communities and euriphagous (Hodek \& Michaud, 2008).

Although there are many studies that evaluate the effects that feeding on several different species of aphids have on the life history traits of these coccinellids there are few that evaluate the effects of feeding on the chrysanthemum aphid Macrosiphoniella sanborni (Gillette) and cabbage aphid Brevicoryne brassicae L. (review by Nedvěd \& Honěk, 
2012). These species of aphids are oligophagous (Blackman \& Eastop, 2000), with M. sanborni a widespread pest on cultivated chrysanthemum throughout the world (Madzdzadeh \& Mehrparvar, 2009) and B. brassicae causing serious damage to cabbage crops (Theunissen, 1989). In addition, the black bean aphid, Aphis fabae (Scopoli), is a common aphid pest of cultivated and self-sown plants and its suitability as prey for coccinellids varies (Nedvěd \& Honěk, 2012).

Biological control is regularly used to control aphids in greenhouses and open field crops (Hodek \& Honěk, 1996; Obrycki \& Kring, 1998). In order to increase the number of biocontrol options, however, there is an increasing need to evaluate more aphidophagous insects. In this context, the effects of M. sanborni, B. brassicae and A. fabae on the survival, growth and development of the immature stages of the aphidophagous coccinellids $C$. septempunctata, $C$. undecimnotata, P. quatuordecimpunctata and $O$. conglobata were studied. In addition, A. fabae was reared on two plant hosts, the common bean and broad bean, in order to evaluate the effect that a host plant can have on the survival and development of these predators.

\section{MATERIAL AND METHODS}

Laboratory cultures of C. septempunctata and C. undecimnotata were established from individuals collected from a peach orchard and an alfalfa field in the area of Arta (Epirus, NorthWestern Greece). Cultures of the coccinellids P. quatuordecimpunctata and $O$. conglobata were established from adults collected from a corn field in the same area. Ladybird beetles were reared on Vicia faba L. (Leguminosae) broad beans infested with Aphis fabae (Scopoli) (Hemiptera: Aphididae) kept in an environmentally controlled room at $24 \pm 1{ }^{\circ} \mathrm{C}$, which lies within the range of temperature within which aphidophagous coccinellids develop and reproduce (e.g. Xia et al., 1999; Papanikolaou et al., 2013), $70 \pm 5 \% \mathrm{RH}$ and a photoperiod of $16 \mathrm{~L}: 8 \mathrm{D}$. The experiments were conducted under these laboratory conditions, using F1 progeny.

Colonies of $A$. fabae and B. brassicae were established from individuals collected from commercial cultures on common bean and cabbage, respectively, whereas M. sanborni were collected from garden grown chrysanthemum plants. Aphis fabae was reared on broad bean plants ( $V . f a b a$, cv. "favino nero") and common bean (Phaseolus vulgaris L., cv. "Aridea"). Macrosiphoniella sanborni was reared on chrysanthemum (Chrysanthemum morifolium (Ramat), cv. "Ariana lime") plants and B. brassicae on cabbage (Brassica oleracea L. var. capitata, cv. "Gianiotica") plants.

Stems of the above mentioned rearing plants with four physiologically mature leaves and bearing a sufficient number of aphids (approximately 150 aphids of all developmental stages) were cut and used in the experiments. Stems were placed individually in transparent $280-\mathrm{ml}$ plastic cups (13.5 $\mathrm{cm}$ upper diameter, $7 \mathrm{~cm}$ base diameter and $12.5 \mathrm{~cm}$ in height). An opening was made at the bottom of the plastic cups through which the lower part of the plant stems were inserted and secured in place by white plasticine that filled the opening. To provide water to the plant stems the cups containing the stems were fitted into similar plastic cups containing a sponge impregnated with water. The top of the plastic cups was covered with organdy gauze to ensure aeration and prevent condensation. Newly hatched larvae of each of the preda- tors were placed individually on the appropriate plant colonized with aphids.

The larvae were provided with fresh prey daily until pupation (about 150 aphids of all developmental stages). The survival and development was recorded on a daily basis. Adults were weighed within 22 to $26 \mathrm{~h}$ of emerging from pupae and prior to feeding. Depending on larval survival when fed on each aphid prey, twenty to one hundred coccinellids were used per species.

The differences in larval and pupal survival of the 4 species of coccinellids each fed on the 4 species of aphids were determined using multiple chi-squares test followed by a Fisher's exact test for pair-wise comparison. To determine the effect of aphid prey on larval and pupal developmental time, and adult weight, the data were submitted to one-way analysis of variance, followed by a LSD test to separate the means. All analyses were done using the statistical package SPSS 14.0 (SPSS Inc., 2004).

\section{RESULTS}

Survival of C. septempunctata immatures fed on all 4 species of aphid was high (Table 1). The lowest survival rate was recorded on $B$. brassicae (73\%) and the highest on $A$. fabae feeding on broad bean plants (100\%). The developmental time of $C$. septempunctata was significantly dependent on the species of aphid prey (Table 2). The total larval developmental time was shortest on $A$. fabae (on both host plants) and longest on $B$. brassicae. Pupae developmental time was similar on all 4 aphids. Adult weight was also affected by aphid prey (Table 2) and the lightest adults were produced by larvae fed on $B$. brassicae.

The immature survival (larvae and pupae) of $C$. undecimnotata ranged between 32.0 to $82.6 \%$ depending on the aphid prey (Table 1). The lowest percentage immature survival of this predator was recorded when the prey was $B$. brassicae or A. fabae reared on common bean, and the highest when larvae were fed on $A$. fabae reared on broad bean. The survival on $A$. fabae reared on common bean was low due to high mortality in the first and second larval instars. Significant differences in developmental time of all the larval instars and total immature developmental time were detected (Table 2). The shortest immature developmental time was recorded when they were fed on $A$. fabae reared on broad bean and M. sanborni (15.8 and 16.4 days, respectively) and the longest when the prey was $B$. brassicae (22.9 days). Pupal duration was not significantly affected by the different species of aphid prey and was approximately 6 days in all cases. Aphid prey significantly affected adult weight. The heaviest adults developed from larvae fed on $A$. fabae reared on broad bean and $M$. sanbor$n i$ (19.1 and $17.6 \mathrm{mg}$, respectively) and the lightest from those reared on $A$. fabae reared on common bean, and $B$. brassicae (14.8 and 13.9, respectively).

Survival of the larval stages of $P$. quatuordecimpunctata was significantly affected by the aphid prey, but not that of the pupal stage (Table 1). Total immature survival was significantly lower for the larvae fed on M. sanborni and $B$. brassicae (25 and $6.8 \%$, respectively) compared to A. fabae $(69.7$ and $76.9 \%$ for $A$. fabae reared on common bean and broad bean, respectively). Total immature developmental time ranged from 13 (A. fabae reared on broad bean) to 19.8 ( $B$. brassicae) days and was significantly 
TABLE 1. Percentage of the larvae and pupae of four species of predatory coccinellids that survived when fed on A. fabae, M. sanborni and B. brassicae.

\begin{tabular}{|c|c|c|c|c|c|c|c|c|}
\hline & $\mathrm{n}$ & L1 & L2 & L3 & L4 & Pupa & Larvae & Total \\
\hline $\begin{array}{l}\text { C. septempunctata } \\
\text { A. fabae (common bean) } \\
\text { A. fabae (broad bean) } \\
\text { M. sanborni } \\
\text { B. brassicae } \\
\chi^{2} \\
\mathrm{P}^{\#}\end{array}$ & $\begin{array}{l}22 \\
20 \\
27 \\
26\end{array}$ & $\begin{array}{l}95.7 \\
100.0 \\
88.9 \\
84.6 \\
4.261 \\
0.235 \\
\end{array}$ & $\begin{array}{l}95.5 \\
100.0 \\
100.0 \\
90.9 \\
3.796 \\
0.264 \\
\end{array}$ & $\begin{array}{l}100.0 \\
100.0 \\
95.8 \\
95.0 \\
1.942 \\
0.586 \\
\end{array}$ & $\begin{array}{l}100.0 \\
100.0 \\
100.0 \\
100.0\end{array}$ & $\begin{array}{c}95.2 \\
100.0 \\
87.0 \\
100.0 \\
5.366 \\
0.147 \\
\end{array}$ & $\begin{array}{c}91.3 \\
100.0 \\
85.2 \\
73.1 \\
7.608 \\
0.055 \\
\end{array}$ & $\begin{array}{c}87.0 \\
100.0 \\
74.1 \\
73.1 \\
6.787 \\
0.079 \\
\end{array}$ \\
\hline $\begin{array}{l}\text { C. undecimnotata } \\
\text { A. fabae (common bean) } \\
\text { A. fabae (broad bean) } \\
\text { M. sanborni } \\
\text { B. brassicae } \\
\chi^{2} \\
\mathrm{P}\end{array}$ & $\begin{array}{l}36 \\
23 \\
25 \\
50\end{array}$ & $\begin{array}{c}52.8 \mathrm{~b}^{\S} \\
87.0 \mathrm{a} \\
96.0 \mathrm{a} \\
80.0 \mathrm{a} \\
18.487 \\
<0.001 \\
\end{array}$ & $\begin{array}{l}63.2 \mathrm{~b} \\
100.0 \mathrm{a} \\
95.8 \mathrm{a} \\
77.5 \mathrm{~b} \\
13.350 \\
<0.001 \\
\end{array}$ & $\begin{array}{l}100.0 \\
95.0 \\
87.0 \\
80.6 \\
4.280 \\
0.233 \\
\end{array}$ & $\begin{array}{l}100.0 \mathrm{a} \\
100.0 \mathrm{a} \\
100.0 \mathrm{a} \\
84.0 \mathrm{a} \\
8.613 \\
0.035 \\
\end{array}$ & $\begin{array}{l}100.0 \mathrm{a} \\
100.0 \mathrm{a} \\
90.0 \mathrm{ab} \\
76.2 \mathrm{~b} \\
8.088 \\
0.044 \\
\end{array}$ & $\begin{array}{l}33.3 \mathrm{~b} \\
82.6 \mathrm{a} \\
80.0 \mathrm{a} \\
42.0 \mathrm{~b} \\
24.392 \\
<0.001 \\
\end{array}$ & $\begin{array}{l}33.3 \mathrm{~b} \\
82.6 \mathrm{a} \\
72.0 \mathrm{a} \\
32.0 \mathrm{~b} \\
25.005 \\
<0.001\end{array}$ \\
\hline $\begin{array}{l}\text { P. quatuordecimpunctata } \\
\text { A. fabae (common bean) } \\
\text { A. fabae (broad bean) } \\
\text { M. sanborni } \\
\text { B. brassicae } \\
\chi^{2} \\
\mathrm{P}\end{array}$ & $\begin{array}{l}33 \\
26 \\
60 \\
88\end{array}$ & $\begin{array}{c}78.8 \mathrm{~b} \\
92.3 \mathrm{a} \\
95.0 \mathrm{a} \\
54.5 \mathrm{c} \\
36.723 \\
<0.001 \\
\end{array}$ & $\begin{array}{c}96.2 \mathrm{a} \\
100.0 \mathrm{a} \\
78.9 \mathrm{~b} \\
43.8 \mathrm{c} \\
38.804 \\
<0.001 \\
\end{array}$ & $\begin{array}{l}96.0 \mathrm{a} \\
95.8 \mathrm{a} \\
60.0 \mathrm{~b} \\
42.9 \mathrm{c} \\
26.064 \\
<0.001 \\
\end{array}$ & $\begin{array}{l}100.0 \mathrm{a} \\
100.0 \mathrm{a} \\
59.3 \mathrm{~b} \\
77.8 \mathrm{ab} \\
21.877 \\
<0.001 \\
\end{array}$ & $\begin{array}{c}95.8 \\
87.0 \\
93.8 \\
85.7 \\
1.583 \\
0.663 \\
\end{array}$ & $\begin{array}{c}72.7 \mathrm{a} \\
88.5 \mathrm{a} \\
26.7 \mathrm{~b} \\
8.0 \mathrm{c} \\
84.682 \\
<0.001 \\
\end{array}$ & $\begin{array}{c}69.7 \mathrm{a} \\
76.9 \mathrm{a} \\
25.0 \mathrm{~b} \\
6.8 \mathrm{c} \\
73.912 \\
<0.001\end{array}$ \\
\hline $\begin{array}{l}\text { O. conglobata } \\
\text { A. fabae (common bean) } \\
\text { A. fabae (broad bean) } \\
\text { M. sanborni } \\
\text { B. brassicae } \\
\chi^{2} \\
\text { P }\end{array}$ & $\begin{array}{c}80 \\
21 \\
80 \\
100\end{array}$ & $\begin{array}{l}22.5 \mathrm{~d} \\
100.0 \mathrm{a} \\
71.3 \mathrm{~b} \\
48.0 \mathrm{c} \\
59.673 \\
<0.001 \\
\end{array}$ & $\begin{array}{l}61.1 \mathrm{bc} \\
100.0 \mathrm{a} \\
78.9 \mathrm{~b} \\
43.8 \mathrm{c} \\
26.410 \\
<0.001 \\
\end{array}$ & $\begin{array}{c}100.0 \mathrm{a} \\
100.0 \mathrm{a} \\
60.0 \mathrm{~b} \\
52.4 \mathrm{~b} \\
19.413 \\
0.001 \\
\end{array}$ & $\begin{array}{c}100.0 \mathrm{a} \\
100.0 \mathrm{a} \\
59.3 \mathrm{~b} \\
81.8 \mathrm{ab} \\
16.074 \\
0.001 \\
\end{array}$ & $\begin{array}{l}90.9 \\
90.5 \\
68.8 \\
66.7 \\
4.630 \\
0.201 \\
\end{array}$ & $\begin{array}{l}13.8 \mathrm{bc} \\
100.0 \mathrm{a} \\
20.0 \mathrm{~b} \\
9.0 \mathrm{c} \\
4.630 \\
<0.001 \\
\end{array}$ & $\begin{array}{l}12.5 \mathrm{~b} \\
90.5 \mathrm{a} \\
13.8 \mathrm{~b} \\
6.0 \mathrm{~b} \\
93.371 \\
<0.001 \\
\end{array}$ \\
\hline
\end{tabular}

${ }^{\S}$ Percentages within a column, for each coccinellid species, followed by different letters differ significantly (Fisher's exact test: $\mathrm{P}<$ 0.05). ${ }^{*}$ All df 3 .

affected by aphid prey. Significant differences in the developmental times were recorded for all larval instars, but pupal developmental duration was independent of aphid prey. The heaviest adults developed from larvae fed on $A$. fabae reared on broad beans followed by those reared on M. sanborni, A. fabae reared on common bean and B. brassicae (the lightest on $B$. brassicae).

The aphid prey had a significant effect on the larvae of $O$. conglobata, but not the pupal stage (Table 1). The percentage survival of the larvae fed on $B$. brassicae, $M$. sanborni and $A$. fabae reared on common bean was very low and total immature survival ranged from 6 to $13.8 \%$. In contrast, the survival of immature stages fed on $A$. fabae reared on broad bean, was significantly higher compared to their survival when fed the other species of aphids (total immature survival 90.5\%). Larval and pupal developmental time and adult weight were also significantly dependent on the species of aphid prey (Table 2). Immature developmental time was shorter for individuals fed on M. sanborni followed by those fed on $A$. fabae and $B$. brassicae. The heaviest adults developed from larvae fed on $A$. fabae followed by those fed on M. sanborni and B. brassicae (the lightest on B. brassicae).

\section{DISCUSSION}

This study provides a comprehensive description of the effect of three aphid species (A. fabae, M. sanborni and $B$. brassicae) on immature survival, development and adult body weights of four common aphidophagous cocinellids (C. septempunctata, C. undecimnotata, P. quatuordecim- punctata and $O$. conglobata). In addition, it provides evidence that an aphid's host plant may also affect a predators' performance. Considering the importance of these coccinellids as biological control agents (Hodek \& Honěk, 1996), these preliminary results are likely to have a bearing on their use in biological control programs. In general, a high percentage survival of immature stages combined with a short developmental time is a desirable characteristic of biological control agents.

This study revealed that $A$. fabae reared on broad bean was a suitable prey for all four coccinellids, based on their survival, larval growth, development and adult fresh weight. Nevertheless, few of the larvae fed on A. fabae on common bean survived, possibly because the neonate larvae were trapped or mortally wounded by the trichomes on the leaves and stems of common bean. Preliminary observations on first instar larvae of $C$. undecimnotata and $O$. conglobata hunting on common bean indicate that some of them died after becoming impaled by the leaf and stem trichomes. In accordance with this observation, Putman (1955) records that the hook-shaped trichomes on the foliage of scarlet runner bean, Phaseolus coccineus, can tear the integument of Stethorus punctillum, which results in its quick death. The larvae of Adalia bipunctata L. are unable to search leaves with dense upright or hook-shaped hairs (Shah, 1982). When larvae were placed on leaves of bush bean (Ph. vulgaris), they spent more than $75 \%$ of the time trapped on leaf trichomes.

The data in the literature on the suitability of $A$. fabae on $V$. faba as prey for several aphidophagous coccinellids 
TABLE 2. Larval and pupal developmental times and adult weights (mean \pm SE) of four species of predatory coccinellids fed on $A$. fabae, M. sanborni and B. brassicae.

\begin{tabular}{|c|c|c|c|c|c|c|c|}
\hline \multirow{2}{*}{ Prey } & \multicolumn{6}{|c|}{ Developmental time (days) } & \multirow{2}{*}{$\begin{array}{l}\text { Adult body } \\
\text { weight }(\mathrm{mg})\end{array}$} \\
\hline & L1 & L2 & L3 & L4 & Pupa & Total & \\
\hline $\begin{array}{l}\text { C. septempunctata } \\
\text { A. fabae (common bean) } \\
\text { A. fabae (broad bean) } \\
\text { M. sanborni } \\
\text { B. brassicae } \\
\mathrm{F}^{\#} \\
\mathrm{P}\end{array}$ & $\begin{array}{l}2.1 \pm 0.1 \mathrm{a}^{\S} \\
2.1 \pm 0.1 \mathrm{a} \\
2.2 \pm 0.1 \mathrm{a} \\
2.1 \pm 0.1 \mathrm{a} \\
0.663 \\
0.577\end{array}$ & $\begin{array}{l}1.9 \pm 0.1 \mathrm{~b} \\
1.9 \pm 0.1 \mathrm{~b} \\
2.1 \pm 0.1 \mathrm{~b} \\
2.4 \pm 0.2 \mathrm{a} \\
3.039 \\
0.034 \\
\end{array}$ & $\begin{array}{l}1.5 \pm 0.1 \mathrm{~b} \\
1.4 \pm 0.1 \mathrm{~b} \\
1.7 \pm 0.1 \mathrm{~b} \\
2.7 \pm 0.1 \mathrm{a} \\
24.314 \\
<0.001 \\
\end{array}$ & $\begin{array}{l}3.8 \pm 0.1 \mathrm{~b} \\
3.7 \pm 0.1 \mathrm{~b} \\
4.0 \pm 0.2 \mathrm{~b} \\
4.4 \pm 0.1 \mathrm{a} \\
4.345 \\
0.007\end{array}$ & $\begin{array}{l}5.3 \pm 0.1 \mathrm{a} \\
5.2 \pm 0.1 \mathrm{a} \\
5.3 \pm 0.1 \mathrm{a} \\
5.0 \pm 0.1 \mathrm{a} \\
1,799 \\
0.155\end{array}$ & $\begin{array}{c}14.6 \pm 0.2 \mathrm{c} \\
14.4 \pm 0.1 \mathrm{c} \\
15.3 \pm 0.3 \mathrm{~b} \\
16.7 \pm 0.2 \mathrm{a} \\
28.541 \\
<0.001\end{array}$ & $\begin{array}{l}35.0 \pm 0.9 \mathrm{a} \\
35.5 \pm 0.8 \mathrm{a} \\
33.8 \pm 0.7 \mathrm{a} \\
31.1 \pm 1.1 \mathrm{~b} \\
\quad 4.375 \\
0.007\end{array}$ \\
\hline $\begin{array}{l}\text { C. undecimnotata } \\
\text { A. fabae (common bean) } \\
\text { A. fabae (broad bean) } \\
\text { M. sanborni } \\
\text { B. brassicae } \\
\text { F } \\
\text { P }\end{array}$ & $\begin{array}{l}3.0 \pm 0.2 \mathrm{a} \\
2.1 \pm 0.1 \mathrm{~b} \\
1.5 \pm 0.1 \mathrm{c} \\
2.6 \pm 0.2 \mathrm{a} \\
16.534 \\
<0.001 \\
\end{array}$ & $\begin{array}{l}1.8 \pm 0.2 \mathrm{~b} \\
1.8 \pm 0.1 \mathrm{~b} \\
1.9 \pm 0.1 \mathrm{~b} \\
3.2 \pm 0.3 \mathrm{a} \\
12.612 \\
0.001 \\
\end{array}$ & $\begin{array}{l}3.2 \pm 0.3 \mathrm{a} \\
1.8 \pm 0.1 \mathrm{~b} \\
2.4 \pm 0.1 \mathrm{~b} \\
3.4 \pm 0.2 \mathrm{a} \\
15.880 \\
<0.001 \\
\end{array}$ & $\begin{array}{l}4.6 \pm 0.3 \mathrm{~b} \\
3.9 \pm 0.1 \mathrm{~b} \\
4.4 \pm 0.1 \mathrm{~b} \\
7.6 \pm 0.4 \mathrm{a} \\
46.405 \\
<0.001 \\
\end{array}$ & $\begin{array}{l}6.1 \pm 0.1 \mathrm{a} \\
6.2 \pm 0.1 \mathrm{a} \\
6.2 \pm 0.1 \mathrm{a} \\
6.1 \pm 0.1 \mathrm{a} \\
0.281 \\
0.839 \\
\end{array}$ & $\begin{array}{c}18.7 \pm 0.5 \mathrm{~b} \\
15.8 \pm 0.2 \mathrm{c} \\
16.4 \pm 0.2 \mathrm{c} \\
22.9 \pm 0.8 \mathrm{a} \\
53.832 \\
<0.001\end{array}$ & $\begin{array}{c}14.8 \pm 0.9 \mathrm{~b} \\
19.1 \pm 0.8 \mathrm{a} \\
17.6 \pm 0.7 \mathrm{a} \\
13.9 \pm 0.3 \mathrm{~b} \\
11.964 \\
0.001 \\
\end{array}$ \\
\hline $\begin{array}{l}\text { P. quatuordecimpunctata } \\
\text { A. fabae (common bean) } \\
\text { A. fabae (broad bean) } \\
\text { M. sanborni } \\
\text { B. brassicae } \\
\text { F } \\
\text { P }\end{array}$ & $\begin{array}{l}2.1 \pm 0.1 \mathrm{~b} \\
2.1 \pm 0.1 \mathrm{~b} \\
3.0 \pm 0.4 \mathrm{a} \\
3.0 \pm 0.1 \mathrm{a} \\
\quad 7.030 \\
<0.001\end{array}$ & $\begin{array}{c}1.5 \pm 0.1 \mathrm{c} \\
1.9 \pm 0.1 \mathrm{~b} \\
1.6 \pm 0.1 \mathrm{bc} \\
2.5 \pm 0.3 \mathrm{a} \\
6.444 \\
0.001\end{array}$ & $\begin{array}{l}2.1 \pm 0.2 \mathrm{~b} \\
1.5 \pm 0.1 \mathrm{c} \\
2.4 \pm 0.1 \mathrm{~b} \\
4.6 \pm 0.3 \mathrm{a} \\
33.991 \\
<0.001\end{array}$ & $\begin{array}{l}2.9 \pm 0.1 \mathrm{~b} \\
2.8 \pm 0.2 \mathrm{~b} \\
2.8 \pm 0.1 \mathrm{~b} \\
5.2 \pm 0.2 \mathrm{a} \\
22.461 \\
<0.001\end{array}$ & $\begin{array}{l}4.9 \pm 0.1 \mathrm{a} \\
4.7 \pm 0.1 \mathrm{a} \\
4.6 \pm 0.1 \mathrm{a} \\
4.5 \pm 0.3 \mathrm{a} \\
1.175 \\
0.327\end{array}$ & $\begin{array}{c}13.4 \pm 0.2 \mathrm{c} \\
13.0 \pm 0.3 \mathrm{c} \\
14.4 \pm 0.3 \mathrm{~b} \\
19.8 \pm 0.3 \mathrm{a} \\
51.360 \\
<0.001\end{array}$ & $\begin{array}{c}7.0 \pm 0.3 \mathrm{~b} \\
8.2 \pm 0.3 \mathrm{a} \\
7.2 \pm 0.3 \mathrm{~b} \\
5.3 \pm 0.8 \mathrm{c} \\
8.527 \\
<0.001\end{array}$ \\
\hline $\begin{array}{l}\text { O. conglobata } \\
\text { A. fabae (common bean) } \\
\text { A. fabae (broad bean) } \\
\text { M. sanborni } \\
\text { B. brassicae } \\
\text { F } \\
\text { P }\end{array}$ & $\begin{array}{l}3.9 \pm 0.3 \mathrm{a} \\
3.0 \pm 0.1 \mathrm{a} \\
3.1 \pm 0.4 \mathrm{a} \\
3.2 \pm 0.2 \mathrm{a} \\
2.315 \\
0.09\end{array}$ & $\begin{array}{l}1.9 \pm 0.2 \mathrm{a} \\
1.6 \pm 0.2 \mathrm{a} \\
2.0 \pm 0.2 \mathrm{a} \\
2.5 \pm 0.3 \mathrm{a} \\
2.230 \\
0.099\end{array}$ & $\begin{array}{l}2.5 \pm 0.3 \mathrm{~b} \\
2.5 \pm 0.2 \mathrm{~b} \\
2.4 \pm 0.2 \mathrm{~b} \\
4.8 \pm 0.2 \mathrm{a} \\
16.057 \\
<0.001\end{array}$ & $\begin{array}{l}4.4 \pm 0.3 \mathrm{ab} \\
3.9 \pm 0.2 \mathrm{~b} \\
3.6 \pm 0.3 \mathrm{~b} \\
5.2 \pm 0.3 \mathrm{a} \\
4.829 \\
0.006\end{array}$ & $\begin{array}{c}5.8 \pm 0.1 \mathrm{a} \\
5.8 \pm 0.2 \mathrm{a} \\
4.7 \pm 0.2 \mathrm{~b} \\
4.8 \pm 0.3 \mathrm{~b} \\
14.788 \\
<0.001\end{array}$ & $\begin{array}{c}18.5 \pm 0.5 \mathrm{~b} \\
16.9 \pm 0.4 \mathrm{c} \\
15.9 \pm 0.6 \mathrm{c} \\
20.5 \pm 0.3 \mathrm{a} \\
12.609 \\
<0.001\end{array}$ & $\begin{array}{c}6.9 \pm 0.4 \mathrm{a} \\
7.9 \pm 0.4 \mathrm{a} \\
5.5 \pm 0.3 \mathrm{~b} \\
4.3 \pm 0.4 \mathrm{~b} \\
11.090 \\
<0.001\end{array}$ \\
\hline
\end{tabular}

${ }^{\S}$ Means within a column, for each coccinellid species, followed by different letters differ significantly (LSD test: $\mathrm{P}<0.05$ ). ${ }^{\#} \mathrm{df}$ for all C. septempunctata $=3,74$; for $C$. undecimnotata $=3,61$; for $P$. quatuordecimpunctata $=3,60$ and for $O$. conglobata $=3,42$.

are contradictory. Kontodimas et al. (2008) report that $A$. fabae on $V$. faba is highly suitable for the pre-imaginal development and adult reproduction of three species of coccinellid (C. septempunctata, C. undecimnotata and $P$. quatuordecimpunctata), whereas Cabral et al. (2006) record a low percentage survival of $C$. septempunctata larvae fed $A$. fabae (total immature survival about $50 \%$ ). In addition, $C$. septempunctata larvae fed $A$. fabae reared on either a partially resistant variety or a susceptible variety of $V$. fabae differ significantly in their ability to convert food to body mass as well as in their immature developmental time (Shannag \& Obeidat, 2006, 2008). Although differences between studies may be partially attributed to different experimental protocols, they may also be due to plantherbivore-predator interactions not only at a plant species level but also at the cultivar level. Finally, another problem encountered when evaluating data in the literature on the suitability of $A$. fabae as prey for coccinellid predators was pointed out in a recent review by Hodek \& Evans (2012). Given that $A$. fabae host adapted biotypes have been redefined as different species and in some studies the aphid host plant is not reported, Hodek \& Evans highlighted an important issue concerning the correct taxonomic identification of the aphids used in studies evaluating the suitability of "A. fabae" as prey in terms of coccinellid life history parameters. Thus, it is suggested that aphid host plants must be precisely identified so that the species of aphid can be correctly identified.
The present study also indicated that the survival of $P$. quatuordecimpunctata and O. conglobata fed on $M$. sanborni was lower than that recorded for C. septempunctata and $C$. undecimnotata. Leaves of $C$. morifolium are a well-documented source of secondary metabolites (Kil \& Lee, 1987; Hu \& Chen, 1997). Beninger et al. (2004) record a flavanone and two phenolic acids in leaves of $C$. morifolium, which are biologically active against two phytophagous caterpillars, the cabbage looper (Trichoplusia ni Hubner) and gypsy moth (Lymantria dispar L.). Leiss et al. (2009) report that two phenylpropanoids, chlorogenic acid and feruloyl quinic acid, determine the resistance of chrysanthemum (Dendranthema grandiflora Tzvelev) to western flower thrips, Frankliniella occidentalis (Pergande). Similarly, Traugott \& Stamp (1997) report that chlorogenic acid sequestered by Manduca sexta L. from its host plant has a negative effect on the performance of the insect predator, Podisus maculiventris Say. Macrosiphoniella sanborni may sequester allelochemicals from chrysanthemum host plants and use them as a means of defence against its natural enemies.

Brevicoryne brassicae had deleterious effects on the performance of the coccinellids tested, in terms of a low percentage survival of larvae (except for C. septempunctata), increase in the developmental time of the larvae and reduction in the weight of the adults. These results are in accordance with those of other studies that report that feeding on $B$. brassicae has negative effects on the performance of aphidophagous predators such as coccinellid beetles, hov- 
erflies and lacewings (Francis et al., 2001b; Vanhaelen et al., 2002; Tsaganou et al., 2004; Kazana et al., 2007; Pratt, 2008; Chaplin-Kramer et al., 2011; Kos et al., 2011, 2012). The cabbage aphid, B. brassicae, is a specialist herbivore that sequesters glucosinolates from its host plant as a defense against its predators (Francis et al., 2002; Kazana et al., 2007; Pratt, 2008; Kos et al., 2011, 2012). It contains an endogenous myrosinase, which is stored separately from the glucosinolates but when attacked by a predator the sequestered glucosinolates come into contact with the aphid myrosinase resulting in the formation of hydrolytic products that are toxic for aphid predators (Jones et al., 2001; Bridges et al., 2002; Francis et al., 2002; Kos et al., 2011, 2012). Although the role of the chemical defence of $B$. brassicae against predators is well documented, another factor might also contribute to the low quality of $B$. brassicae as potential prey, i.e. its morphological characteristics associated with the waxy substances covering its body and the entire colony. These features may hinder the capture of aphids or make them less attractive to predators (Hodek \& Honěk, 1996). In addition, morphological characteristics of the surface of cabbage leaves i.e. smooth waxy surface may affect a predator's mobility and make it more difficult for them to catch the aphids.

In conclusion, this study provides detailed information on the performance of C. septempunctata, C. undecimnotata, P. quatuordecimpunctata and O. conglobata fed $A$. fabae, M. sanborni and B. brassicae. We expect the results to have bearing on the use of these common and widespread coccinellids as biological control agents and the efficient breeding of these predators in an insectary. However, further information on their life table parameters, and functional and numerical responses when exploiting different prey, is needed for a better understanding of the role of these predators in regulating aphid abundance.

ACKNOWLEDGEMENTS. Authors would like to thank F. Karamaouna (Benaki Phytopathological Institute) for critical and constructive comments on an earlier draft of this manuscript.

\section{REFERENCES}

Aslan M.M. \& Uygun N. 2005: The aphidophagous coccinellid (Coleoptera: Coccinellidae) species in Kahramanmaraş, Turkey. - Turk. J. Zool. 29: 1-8.

Beninger C.W., Abou-Zaid M.M., Kistner A.L.E., Hallett R.H., IQBAL M.J., Grodzinski B. \& Hall J.C. 2004: A flavanone and two phenolic acids from Chrysanthemum morifolium with phytotoxic and insect growth regulating activity. -J. Chem. Ecol. 30: 589-606.

Blackman R.L. \& Eastop V.F. 2000: Aphids on the World's Crops. An Identification and Information Guide. 2nd ed. John Wiley \& Sons, Chichester, $476 \mathrm{pp}$.

Bridges M., Jones A.M.E, Bones A.M., Hodgson C., Cole R., Bartlet E., Wallsgrove R., Karapapa V.K., Watts N. \& RosSITER J.T. 2002: Spatial organization of the glucosinolate-myrosinase system in brassica specialist aphids is similar to that of the host plant. - Proc. R. Soc. Lond. (B) 269: 187-191.

Cabral S., Soares A.O., Moura R. \& Garcia P. 2006: Suitability of Aphis fabae, Myzus persicae (Homoptera: Aphididae) and Aleyrodes proletella (Homoptera: Aleyrodidae) as prey for
Coccinella undecimpunctata (Coleoptera: Coccinellidae). Biol. Contr. 39: 434-440.

Carter M.C., Sutherland D. \& Dixon A.F.G. 1984: Plant structure and the searching efficiency of coccinellid larvae. - Oecologia (Berlin) 63: 394-397.

Chaplin-Kramer R., Kliebenstein D.J., Chiem A., Morrill E., Mills N. \& Kremen C. 2011: Chemically mediated tritrophic interactions: opposing effects of glucosinolates on a specialist herbivore and its predators. - J. Appl. Ecol. 48: 880-887.

Clark T.L. \& Messina F.J. 1998: Plant architecture and the foraging success of ladybird beetles attacking the Russian wheat aphids. - Entomol. Exp. Appl. 86: 153-161.

DMitriew C. \& Rowe L. 2011: The effects of larval nutrition on reproductive performance in a food-limited adult environment. - PLOS ONE 6: e17399.

Francis F., Haubruge E., Hastir M.P. \& Gaspar C. 2001a: Effects of aphid host plant on development and reproduction of the third trophic level, the predator Adalia bipunctata (Coleoptera: Coccinellidae). - Environ. Entomol. 30: 947-952.

Francis F., Lognay G., Wathelet J.P. \& Haubruge E. 2001b: Effects of allelochemicals from first (Brassicaceae) and second (Myzus persicae and Brevicoryne brassicae) trophic levels on Adalia bipunctata. - J. Chem. Ecol. 27: 243-256.

Francis F., Lognay G., Wathelet J.P. \& Haubruge E. 2002: Characterisation of aphid myrosinase and degradation studies of glucosinolates. - Arch. Insect Biochem. Physiol. 50: 173-182.

Freier B., Triltsch H., Mowes M. \& Moll E. 2007: The potential of predators in natural control of aphids in wheat: Results of a ten-year field study in two German landscapes. - BioControl 52: 775-788.

Giles K.L., Madden R.D., Stockaland R., Payton M.E. \& DillWITH J.W. 2002: Host plants affect predator fitness via the nutritional value of herbivore prey: investigation of a plant-aphidladybeetle system. - BioControl 47: 1-12.

Hauge M.S., Nielsen F.H. \& Toft S. 1998: The influence of three cereal aphid species and mixed diet on larval survival, development and adult weight of Coccinella septempunctata. - Entomol. Exp. Appl. 89: 319-322.

Hodek I. 1993: Habitat and food specificity in aphidophagous predators. - Biocontr. Sci. Technol. 3: 91-100.

Hodek I. \& Evans E.W. 2012: Food relationships. In Hodek I., van Emden H.F. \& Honěk A. (eds): Ecology and Behaviour of the Ladybird Beetles (Coccinellidae). Wiley-Blackwell, Chichester, pp. 141-274.

Hodek I. \& HonĚK A. 1996: Ecology of Coccinellidae. Kluwer Academic Publishers, Dordrecht, $464 \mathrm{pp}$.

Hodek I. \& Michaud J.P. 2008: Why is Coccinella septempunctata so successful? (A point-of-view). - Eur. J. Entomol. 105: $1-12$.

HoNĚK A. 1985: Habitat preferences of aphidophagous coccinellids (Coleoptera). - Entomophaga 30: 253-264.

Hu L. \& CHEN Z. 1997: Sesquiterpenoid alcohols from Chrysanthemum morifolium. - Phytochemistry 44: 1287-1290.

IPERTI G. 1999: Biodiversity of predaceous coccinellidae in relation to bioindication and economic importance. - Agr. Ecosyst. Environ. 74: 323-342.

Jones A.M.E, Bridges M., Bones A.M., Cole R. \& Rossiter J.T. 2001: Purification and characterisation of a non-plant myrosinase from the cabbage aphid Brevicoryne brassicae (L.). Ins. Biochem. Mol. Biol. 31: 1-5.

Kalushrov P. \& Hodek I. 2004: The effects of thirteen species of aphids on some life history parameters of the ladybird Coccinella septempunctata. - BioControl 49: 21-32.

Kamo T., Tokuoka Y. \& MiYazaki M. 2010: Influence of aphidhost plant pairs on the survivorship and development of the 
multicolored Asian ladybird beetle: implications for the management of vegetation in rural landscapes. - Ecol. Res. 25: $1141-1149$

Katsoyannos P., Kontodimas D. \& Stathas G. 2005: Summer diapause and winter quiescence of Hippodamia (Semiadalia) undecimnotata (Coleoptera: Coccinellidae) in central Greece. - Eur. J. Entomol. 102: 453-457.

Kavallieratos N.G., Athanassiou C.G., Tomanovic Z., PapadoPOULOS G.D. \& VAYIAS B.J. 2004: Seasonal abundance and effects of predators (Coleoptera, Coccinellidae) and parasitoids (Hymenoptera: Braconidae, Aphidiinae) on Myzus persicae (Hemiptera, Aphidoidea) densities on tobacco: a two-year study from central Greece. - Biologia (Bratislava) 59: 613619.

Kazana E., Pope T.W., Tibbles L., Bridges M., Pickett J.A., Bones A.M., Powell G. \& Rossiter J.T. 2007: The cabbage aphid: a walking mustard oil bomb. - Proc. R. Soc. Lond. (B) 274: 2271-2277.

Khan I., Din S., Khalil S.K. \& Rafi M.A. 2007: Survey of predatory coccinellids (Coleoptera: Coccinellidae) in the Chitral district, Pakistan. - J. Insect Sci. 7(7): 1-6.

KIL B.-S. \& LeE S.Y. 1987: Allelopathic effects of Chrysanthemum morifolium on germination and growth of several herbaceous plants. - J. Chem. Ecol. 13: 299-308.

Kontodimas D.C., Milonas P.G., Stathas G.J., Papanikolaou N.E., Skourti A. \& Matsinos Y.G. 2008: Life table parameters of the aphid predators Coccinella septempunctata, Ceratomegilla undecimnotata and Propylea quatuordecimpunctata (Coleoptera: Coccinellidae). - Eur. J. Entomol. 105: 427-430.

Kos M., Houshyani B., Achhami B.B., Wietsma R., Gols R., Weldegergis B.T., Kabouw P., Bouwmeester H.J., Vet L.E.M., DiCKE M. \& LOON J.J.A. 2012: Herbivore-mediated effects of glucosinolates on different natural enemies of a specialist aphid. - J. Chem. Ecol. 38: 100-115.

Kos M., Kabouw P., Noordam R., Hendriks K., Vet L.E.M., Van Loon J.J.A. \& Dicke M. 2011: Prey-mediated effects of glucosinolates on aphid predators. - Ecol. Entomol. 36: 377-388.

Legrand A. \& Barbosa P. 2003: Plant morphological complexity impacts foraging efficiency of adult Coccinella septempunctata L. (Coleoptera: Coccinellidae). - Environ. Entomol. 32: 1219-1226.

Leiss K.A., Maltese F., Choi Y.H., Verpoorte R. \& Klinkhamer P.G.L. 2009: Identification of chlorogenic acid as a resistance factor for thrips in Chrysanthemum. - Plant Physiol. 150: $1567-1575$.

Madzdzadeh S.M. \& Mehrparvar M. 2009: Morphological discrimination of geographical populations of Macrosiphoniella sanborni (Gillette, 1908) (Hem.: Aphididae) in Iran. - NorthWest. J. Zool. 5: 338-348.

NEDVĚD O. \& HoNĚK A. 2012: Life history and development. In Hodek I., van Emden H.F. \& Honěk A. (eds): Ecology and Behaviour of the Ladybird Beetles (Coccinellidae). Wiley-Blackwell, Chichester, pp. 54-109.

OBRYCKi J.J. \& KRING T.J. 1998: Predaceous coccinellidae in biological control. - Annu. Rev. Entomol. 43: 295-321.

Obrycki J.J., OrR D.B., OrR C.J., Wallendorf M. \& Flanders R.V. 1993: Comparative developmental and reproductive biology of three populations of Propylea quatuordecimpunctata (Coleoptera: Coccinellidae). - Biol. Contr. 3: 27-33.

Omkar \& Pervez A. 2005: Ecology of two-spotted aphidophagous ladybird, Adalia bipunctata: a review. - J. Appl. Entomol. 129: 465-474.
Papanikolaou N.E., Milonas P.G., Kontodimas D.C., Demiris N. \& Matsinos Y.G. 2013: Temperature-dependent development, survival, longevity, and fecundity of Propylea quatuordecimpunctata (Coleoptera: Coccinellidae). - Ann. Entomol. Soc. Am. 106: 228-234.

Pervez A. \& Omkar 2006: Ecology and biological control application of multicoloured Asian ladybird, Harmonia axyridis: a review. - Biocontr. Sci. Technol. 16: 112-128.

Pervez A. \& OmKar 2011: Ecology of aphidophagous ladybird Propylea species: A review. - J. Asia-Pac. Entomol. 14: 357365.

PratT C. 2008: Accumulation of glucosinolates by the cabbage aphid Brevicoryne brassicae as a defense against two coccinellid species. - J. Chem. Ecol. 34: 323-329.

Price P.W., Bouton C.E., Gross P., McPheron B.A., Thompson J.N. \& WeIs A.E. 1980: Interaction among three trophic levels: influence of plant on interaction between insect herbivores and natural enemies. - Annu. Rev. Ecol. Evol. Syst. 11: 41-65.

Putman W.L. 1955: Bionomics of Stethorus punctillum Weise in Ontario. - Can. Entomol. 87: 9-33.

Sнан M.A. 1982: The influence of plant surfaces on the searching behaviour of Coccinellid larvae. - Entomol. Exp. Appl. 31: 377-380.

Shannag H.K. \& Obeidat W.M. 2006: Voracity and conversion efficiency by larvae of Coccinella septempunctata L. (Coleoptera: Coccinellidae) on Aphis fabae Scop. (Homoptera: Aphididae) reared on two faba bean cultivars with different levels of resistance. - Appl. Entomol. Zool. 41: 521-527.

ShanNag H.K. \& OBeidat W.M. 2008: Interaction between plant resistance and predation of Aphis fabae (Homoptera: Aphididae) by Coccinella septempunctata (Coleoptera: Coccinellidae). - Ann. Appl. Biol. 152: 331-337.

SPSS 2004: SPSS 14 for Windows User's Guide. SPSS, Chicago, IL, USA.

THEUNISSEN N. 1989: Integrated control of aphids on field-grown vegetables. In Minks A.K. \& Harrewijn P. (eds): Aphids, their Biology, Natural Enemies and Control. Vol. C. Elsevier, Amsterdam, pp. 285-289.

Traugott M.S. \& Stamp N.E. 1997: Effects of chlorogenic acidand tomatinefed caterpillars on performance of an insect predator. - Oecologia 109: 265-272.

Tsaganou F.C., Hodgson C.J., Athanassiou C.G., Kavallieratos N.G. \& Tomanovic Z. 2004: Effect of Aphis gossypii Glover, Brevicoryne brassicae (L.), and Megoura viciae Buckton (Hemiptera: Aphidoidea) on the development of the predator Harmonia axyridis (Pallas) (Coleoptera: Coccinellidae). - Biol. Contr. 31: 138-144.

VANHAELEn N., Gaspar C. \& Francis F. 2002: Influence of prey host plant on a generalist aphidophagous predator: Episyrphus balteatus (Diptera: Syrphidae). — Eur. J. Entomol. 99: 561564.

Wheeler A.G.J. 1990: Propylea quatuordecimpunctata: Additional U.S. records of an adventive lady beetle (Coleoptera: Coccinellidae). - Entomol. News 101: 164-165.

YAŞAR B. \& ÖZGER S. 2005: Functional response of Oenopia conglobata (L.) (Coleoptera: Coccinellidae) on Hyalopterus pruni (Geoffroy) (Homoptera: Aphididae) in three different size arenas. - Turk. J. Entomol. 29: 91-99.

XIA J.Y., VAN DER WeRF W. \& RABbinge R. 1999: Temperature and prey density on bionomics of Coccinella septempunctata (Coleoptera: Coccinellidae) feeding on Aphis gossypii (Homoptera: Aphididae) on cotton. - Environ. Entomol. 28: 307-314.

Received June 6, 2014; revised and accepted March 19, 2015 Prepublished online May 15, 2015 